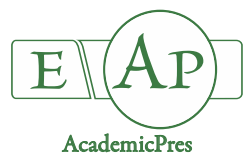

\title{
Phytosociology, Distribution and Ecology of a Willow Community with False Tamarisk from the Lotru Valley (Romanian Carpathians)
}

\author{
Ilie Silvestru NUȚ $\breve{A}^{1}$, Mariana NICULESCU ${ }^{2 *}$ \\ ${ }^{1}$ Dolj Forestry Division, 19 Iancu Jianu Street, Craiova, Romania; silvestru1969@yahoo.com \\ ${ }^{2}$ University of Craiova, Faculty of Agronomy, 19 Libertatii Street, 200583, Craiova, Romania; \\ mniculescum@yahoo.com (*corresponding author)
}

\begin{abstract}
The overall objective of this research was to contribute to a better knowledge of the phytosociology, ecology and distribution of the plant community formed by Myricaria germanica (false tamarisk) and the willow species Salix purpurea. This plant community has an important role in reducing the speed and strength of the water flow during floods. The description was based on cover-abundance data for the faithful, dominant, characteristic and companion species of this plant community. A predominance of Myricaria germanica was observed when analysing the phytocoenoses, as the species finds in this area favourable ecological conditions for an abundant development. Salix purpurea presents a small abundance-dominance or in some phytocoenoses may even lack. The field research also revealed the excessive development of the species Calamagrostis pseudophragmites in some areas, related mostly with the effect of human activities. The anthropogenic disorders have induced modifications in the floristic physiognomy and compositions of the phytocoenoses, favouring also the invasion of opportunistic species such as Ambrosia artemisiifolia, Impatiens glandulifera, Phytolacca amearicana, Amorpha fruticosa, Erigeron annuus, which continuously extend in the studied territory. As Myricaria germanica and Salix purpurea phytocoenoses suffer a great decline throughout Europe, the habitat built by these species was declared of interest and was included in the Habitats Directive.
\end{abstract}

Keywords: biodiversity; habitat; human impact; phytocoenoses; vegetation

\section{Introduction}

A good knowledge of plant communities is essential for the conservation of the natural heritage and for developing sustainable landscape management strategies. The diversity of the relief, climate and soil types in Romania determine also a high diversity of species, habitats, and landscapes.

The identification of the plant communities from an area and their description and analysis from ecological, chorological, syntaxonomical, and sindynamical perspectives has a great importance from the scientific and practical point of view. The flora and vegetation of the study area is characteristic to the Carpathians Mountains, with some particularities related to the local conditions (relief, altitude, climate, nature of rocks and soil). This paper describes an analysis of the physiognomy, floristic composition, distribution and ecology of the Salici purpureae-Myricarietum germanicae Moor 1958 plant community from the Lotru Valley.

The stands with false tamarisk are 1-2.5 m high. They occur on gravelly river terraces, especially on those that are not affected by the strongest current during floods (Chytrý, 2013).

Myricaria germanica was identified in Romania in the $19^{\text {th }}$ century in river valleys at low altitudes, such as in the low meadow of Olt. The Lotru Valley still offers conditions for installing pioneering vegetation with Myricaria germanica.

The shrubbery of Myricaria germanica (false tamarisk), usually growing with different willow species, has an outstanding ecological role in mitigating the speed of water leakage during floods, and therefore has a great conservative value.

Myricaria germanica and Salix purpurea phytocoenoses have drastically decreased in Europe. This plant community is included in Natura 2000 habitat 3230 "Alpine rivers and their ligneous vegetation together with Myricaria germanica", as habitat of community interest included in the Habitats Directive. In addition, the habitats with willows and false tamarisk have a great conservative value, are Emerald protected and are still well preserved in Romania. The habitat is included in the EUNIS level 2 list 
622

and the Berne Convention (31.1) (Nicolin et al., 2008). There are 18 Natura 2000 SCIs in Romania that also include this type of habitats.

Salici purpureae-Myricarietum plant community installed on the river banks constitute a habitat characteristic for two species of birds, Actitis bypoleucos (common sandpiper) and Charadrius dubius (little ringed plover). Both species are included in the IUCN Red List of Threatened Species 2018. Some populations of these two bird species have experienced regression due to human intervention in the nesting areas.

The destruction in the Lotru basin of some phytocoenoses of this plant community at the limit of contact with spruce stands, due to massive deforestation in the last 10 years, and to effects of pollution, had and still has negative effects on the populations of these two bird species. In its spreading area, the false tamarisk is also the only food source for certain phytophagous insects such as the weevil Coniatus splendidus or the bug Tuponia prasina (Donita et al., 2005). The species prefers wetlands, but it hardly tolerates flooded lands, only (up to 1 month). The existence of the habitat with Myricaria germanica is conditioned by the irregular regime of the water drainage and the accumulation of new gravel and alluvial soil. If floods destroy the vegetation with Myricaria germanica, it regenerates after the water has withdrawn.

Myricaria germanica is a typical species of the shrubby pioneer vegetation (Salici-Myricarietum and Salicetum elaeagni) on gravel bars and is restricted to this habitat in Europe, which has been decreasing rapidly in the last 50 years due to the loss of the natural river dynamics as a result of the construction of dams (Müller and Scharm, 2001).

The study of the plant community of willow with false tamarisk, and especially the analysis of the effects of human activities on its extension and composition is of great interest because its ecological importance and scarcity at present.
Myricaria germanica was evaluated according to the criteria of the IUCN Red List Cathegories as "Critically Endangered" (Marinov et al., 2017) Such studies present an important tool for implementing conservation strategies that could insure the maintenance of this type of habitat in a less modified state. A major emphasis has to be put on the preservation of the few remaining sites where Myricaria germanica is present and the reestablishment of suitable habitats (Schletterer and Scheiber, 2008). The aim of the present study was to analyse the chorology, floristic composition and the phytosociology of false tamarisk and willow communities from the Basin of the Lotru River, located in the Southen Carpathians (Romania). By a detailed analysis of floristic composition and dynamics of vegetation in the area, anthropogenic disorders can be detected and conservation strategies can be further adopted.

\section{Materials and Methods}

\section{The study area}

The study area is located in in the Basin of the Lotru River, Southern Carpathian Mountains in Romania. Lotru River has a significant water flow and a special strength and its springs are found at Calcescu Lake in Parangul Mare Mountain, lake of glacial origin. The phytocoenoses of the plant community analyzed are located on floodplains in mountain meadows on alluvial soils in the area of Lotru Valley and its affluents (Macesului, Stan, Latoritei, Stefanul, Purul, Vidruta, Hanesu, Manaileasa, Pravatu, Balindrul Valleys), at an altitudinal range from 750 to $1480 \mathrm{~m}$ (Fig. 1).

Phytocoenoses of this plant community have been analyzed in the following locations: $45^{\circ} 23^{\prime} 3^{\prime \prime}-23^{\circ} 37^{\prime} 42^{\prime \prime}$; 452 $33^{\prime} 41^{\prime \prime}-23^{\circ} 37^{\prime} 41^{\prime \prime} ; \quad 45^{\circ} 23^{\prime} 39^{\prime \prime}-23^{\circ} 37^{\prime} 38^{\prime \prime}$; $\quad 45^{\circ} 23^{\prime} 04^{\prime \prime}-$ $23^{\circ} 37^{\prime} 25^{\prime \prime} ; \quad 45^{\circ} 23^{\prime} 02^{\prime \prime}-23^{\circ} 37^{\prime} 22^{\prime \prime} ; \quad 45^{\circ} 23^{\prime} 01^{\prime \prime}-23^{\circ} 37^{\prime} 20^{\prime \prime}$; $45^{\circ} 23^{\prime} 38,01^{\prime \prime}-23^{\circ} 37^{\prime} 35,01^{\prime \prime}$; $45^{\circ} 21^{\prime} 55^{\prime \prime}-23^{\circ} 50^{\prime} 02^{\prime \prime}$; $45^{\circ} 22^{\prime} 02^{\prime \prime}$ $23^{\circ} 48^{\prime} 23^{\prime \prime} ; \quad 45^{\circ} 22^{\prime} 09^{\prime \prime}-23^{\circ} 47^{\prime} 39^{\prime \prime}$; $\quad 45^{\circ} 22^{\prime} 32^{\prime \prime}-23^{\circ} 52^{\prime} 55^{\prime \prime}$ (Northern latitude and Eastern longitude).

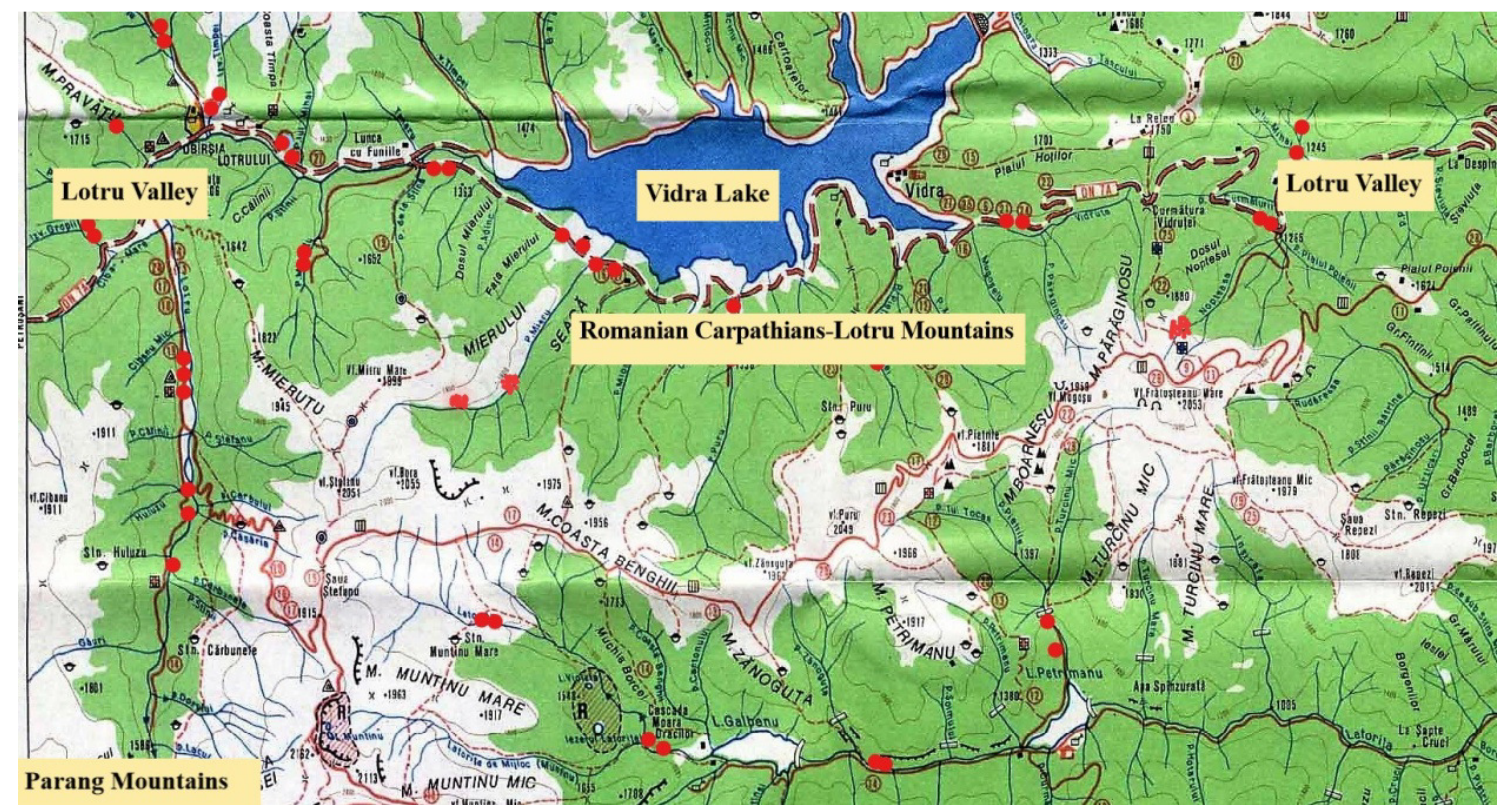

Fig. 1. Location of the studied Myricaria germanica and Salix purpurea phytocoenoses 
The climate of the area is temperate-continental, with the following mean temperature values: spring $+2.2^{\circ} \mathrm{C}$; summer $+11.7^{\circ} \mathrm{C}$, autumn $+5.0^{\circ} \mathrm{C}$; in winter $-4.0^{\circ} \mathrm{C}$. The average temperature during the vegetation season is $11.5^{\circ} \mathrm{C}$. In the study area, the soils are developed on the deep alluvial deposits with parent material derived from the Lotru Valley.

\section{Methods}

Prior to the field work an extensive literature survey was performed, regarding the physical-geographical frame: the relief, the geology and lithology, the hydrographic network, the soils and the general and local climate.

The floristic composition analysis was based on Romanian Flora, vol. I-XII (1952-1976); Flora Europaea, vol. I-V (1964-1980) and The Romania illustrated Flora Pteridophyta et Spermatophyta (Ciocârlan, 2000).

For the syntaxonomic analysis was used the methodology of phyto-sociologic research of the Central European Phyto-Sociologic School, which is based on the principles and methods elaborated by Braun-Blanquet (1939), widely used in modern phytosociological and ecological studies (e.g. Brown et al., 2013; Brandt et al., 2018; Thiele et al. 2018). The plant communities were identified according to the characteristic, faithful, dominant and differential species. For the classification and the phytosociological study were used synthesis papers on the Romanian (Coldea, 1991, 2015) and European vegetation (Mucina et al., 1993; Rodwell et al., 2002; Mucina et al., 2015). The environmental analysis included altitude, slope, aspect, and soil properties.
The size of the sample areas was established according to the type of vegetation: $25-100 \mathrm{~m}^{2}$ for underwoods. The synthetic tables of the described plant community contain information referring to: number of relevés, altitude (m.a.s.l), exposure, inclination (in grades), the completion of the crowning (where it is the case), vegetation level of covering $(\%)$ and the analyzed surface $\left(\mathrm{m}^{2}\right)$.

The vertical arrangement of the phytosociological tables was performed according to the coenotaxonomic criterion. The quantitative participation of every species to the plant community was assessed by the abundance-dominance index, according to the Braun-Blanquet scale. The constancy of species $(\mathrm{K})$ of this plant community was also registered.

The plant community was analyzed and characterized from the chorologic-ecologic point of view, according to their floristic composition and physiognomy, syndynamics and conservation status. For habitat type identification was used the "Romanian Manual for interpretation of EU habitats" (Mountford and Gafta, 2008) and Council Directive 92/43/EEC (of 21 May 1992) on the conservation of natural habitats and of wild fauna and flora.

Data analysis was performed using Syn-Tax 2000 statistic package. Following indexes were calculated: BrayCurtis quantitative index, Sørensen qualitative index, correlation index, using the Group-Average method (UPGMA) and Jaccard coefficient (for binary data), using the Simple Average method (WPGMA) and clustering through dendrograms (Podani, 2001).

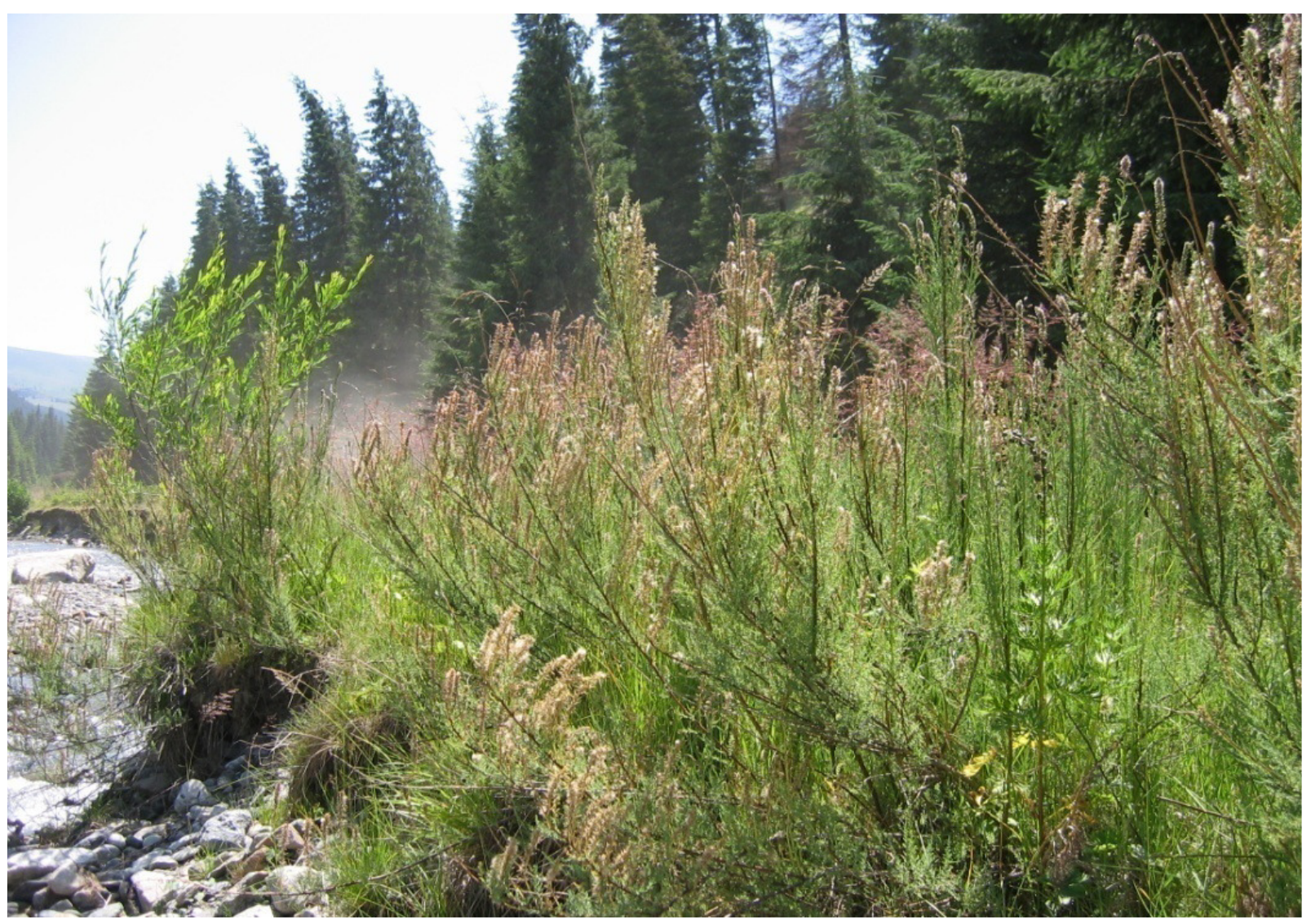

Fig. 2. Salici purpureae-Myricarietum Moor 1958 plant community in Obirsia Lotrului 


\section{Results and Discussion}

The flora and vegetation of the Lotru Valley is characteristic to the Carpathians Mountains. The plant community edified by willow with false tamarisk was identified in several locations in the area of study. This plant community presents a special eco-pedogenetic role.
Phytosociology

The plant community Salici purpureae-Myricarietum germanicae Moor 1958 (Syn.: Myricarietum germanicae Jenik 1955; Myricario germanicae-Epilobietum dodonaei sensu auct. non Aichinger 1933) is classified within the Alliance Salici elaeagno-daphnoidis (Moor 1958) Grass 1993, Order Salicetalia purpureae Moor1958 (Syn.:

Table 1. The floristic structure of willow community with false tamarisk

\begin{tabular}{|c|c|c|c|c|c|c|c|c|c|c|c|}
\hline No. of relevée & 1 & 2 & 3 & 4 & 5 & 6 & 7 & 8 & 9 & 10 & $\mathrm{~K}$ \\
\hline Altitude (m.a.s.l.) & 1050 & 1050 & 1200 & 1200 & 1200 & 1250 & 1250 & 1250 & 1350 & 1350 & \\
\hline Canopy (\%) & 65 & 70 & 75 & 75 & 75 & 60 & 70 & 70 & 65 & 65 & \\
\hline Coverage of herbacaeous layer (\%) & 40 & 40 & 30 & 35 & 45 & 45 & 30 & 25 & 35 & 35 & \\
\hline Area $\left(\mathrm{m}^{2}\right)$ & 100 & 25 & 50 & 100 & 100 & 50 & 50 & 100 & 100 & 50 & \\
\hline \multicolumn{12}{|l|}{ Character species of plant community } \\
\hline Salix purpurea & 1 & 1 & 1 & 1 & 1 & 1 & 1 & 2 & - & 1 & $\mathrm{~V}$ \\
\hline Myricaria germanica & 3 & 4 & 4 & 4 & 4 & 4 & 4 & 3 & 4 & 4 & V \\
\hline \multicolumn{12}{|l|}{$\begin{array}{l}\text { Salicion elaeagno-daphnoides et } \\
\text { Salicetalia purpureae }\end{array}$} \\
\hline Calamagrostis pseudophragmites & 3 & 2 & 1 & 2 & 3 & 3 & 2 & 1 & 2 & 2 & $\mathrm{~V}$ \\
\hline Epilobium dodonaei & + & + & + & + & + & + & + & + & + & 1 & $\mathrm{~V}$ \\
\hline Angelica sylvestris & + & - & + & + & + & - & + & + & + & - & IV \\
\hline Petasites bybridus & + & + & - & - & + & - & - & - & - & - & II \\
\hline Lythrum salicaria & + & + & - & - & + & + & - & - & + & - & III \\
\hline Poa trivialis & - & - & + & + & - & - & + & + & - & + & III \\
\hline Saponaria officinalis & + & + & - & - & + & - & - & - & + & - & III \\
\hline Mentha longifolia & + & + & - & + & + & + & + & - & + & + & IV \\
\hline Lysimachia nummularia & - & + & + & + & - & - & - & - & + & - & II \\
\hline Salix fragilis & + & + & + & - & + & - & + & + & - & + & IV \\
\hline \multicolumn{12}{|l|}{ Saicion triandrae } \\
\hline Salix triandra & - & - & + & - & + & - & + & - & + & - & II \\
\hline Calistegia sepium & + & + & - & - & - & + & - & - & - & - & II \\
\hline Aegopodium podagraria & - & + & + & + & - & - & - & - & + & - & II \\
\hline Rumex obtusifolius & + & + & - & - & + & - & + & + & - & - & III \\
\hline \multicolumn{12}{|l|}{ Alnetea glutinosae } \\
\hline Alnus glutinosa & - & + & + & - & - & + & - & + & - & + & III \\
\hline Impatiens noli-tangere & + & + & - & - & + & + & - & - & + & + & IV \\
\hline Galium palustre & + & + & + & + & + & + & + & + & + & + & V \\
\hline \multicolumn{12}{|l|}{ Alno - Ulmion } \\
\hline Alnus incana (arb.) & + & + & - & - & + & + & + & - & + & + & IV \\
\hline Alnus incana (reg.) & + & + & - & - & - & + & - & - & + & + & III \\
\hline Cirsium oleraceum & + & + & - & - & + & + & + & - & - & - & III \\
\hline Equisetum arvense & + & + & - & - & + & - & - & - & - & - & II \\
\hline Stellaria nemorum & + & + & + & + & + & + & + & + & + & + & V \\
\hline \multicolumn{12}{|l|}{ Fagetalia } \\
\hline Luzula luzuloides & + & + & - & - & + & - & - & - & - & - & II \\
\hline Salvia glutinosa & - & + & - & + & - & + & - & - & - & - & II \\
\hline Cardamine impatiens & - & + & + & - & - & + & - & + & - & + & III \\
\hline Epilobium montanum & - & + & + & + & - & - & - & + & - & + & III \\
\hline Myosotis scorpiodes & - & + & - & + & - & + & - & + & + & - & III \\
\hline \multicolumn{12}{|l|}{ Molinio-Arrhenatheretea } \\
\hline Deschampsia caespitose & + & + & - & - & + & + & - & - & + & + & IV \\
\hline Holcus lanaturs & + & + & + & + & + & + & + & + & + & + & $\mathrm{V}$ \\
\hline Agrostis stolonifera & 1 & 1 & 1 & + & 1 & 1 & 1 & + & 2 & 2 & V \\
\hline
\end{tabular}




\begin{tabular}{|c|c|c|c|c|c|c|c|c|c|c|c|}
\hline Campanula patula & + & - & + & + & + & - & + & + & + & - & IV \\
\hline Ranunculus repens & + & + & + & + & + & + & + & + & + & + & $\mathrm{V}$ \\
\hline Amorpha fruticosa & - & - & + & + & - & - & + & + & - & + & III \\
\hline Erigeron annuus & + & + & + & + & + & + & + & + & + & + & $\mathrm{V}$ \\
\hline Impatiens glandulifera & 1 & 1 & + & + & - & - & + & - & - & - & III \\
\hline Ambrosia artemisiiolia & - & + & - & - & + & + & 2 & 2 & - & - & III \\
\hline Phytolacca amaericana & 1 & 1 & 1 & + & + & + & + & + & 2 & 2 & V \\
\hline Angelica archangelica & + & - & - & + & + & - & - & - & - & - & II \\
\hline Tussilago farfara & 1 & + & 1 & 1 & 1 & + & 1 & 1 & 1 & + & $\mathrm{V}$ \\
\hline Agrostis capillaries & + & + & + & - & + & + & + & - & + & + & IV \\
\hline Rorippa kernerii & + & - & - & + & + & - & - & + & + & - & III \\
\hline Prunella vulgaris & + & + & + & + & + & + & + & + & + & + & $\mathrm{V}$ \\
\hline Leucanthemum vulgare & - & + & - & + & - & + & - & + & - & + & III \\
\hline Carex ovalis & + & - & + & + & + & - & - & - & - & - & III \\
\hline Cerastium holosteoides & + & + & + & + & + & + & - & - & + & + & IV \\
\hline Chrysosplenium alternifolium & - & + & + & + & - & + & - & - & - & + & III \\
\hline Juncus conglomerates & + & + & + & + & + & + & - & - & + & + & IV \\
\hline Juncus effuses & - & + & + & + & - & + & - & - & - & + & III \\
\hline
\end{tabular}

Place and data of the relevés: LotruValley, 18.VI.2016; 21.VII.2017

Salicetalia albae Th. Müller et Görs 1958), and Class Salicetea purpureae Moor 1958 (Coldea et al., 2015).

\section{Physiognomy and floristic composition}

The main species of this plant community are Salix purpurea and Myricaria germanica (Fig. 2). Beside these two species Epilobium dodonaei is considered also as faithful to this plant association.

Salix purpurea presents a small abundance-dominance or in some phytocoenoses may even lack. In the floristic composition there are a series of Salicion-elaeagni and Salicetalia purpureae characteristic species such as: Salix alba, S. fragilis, Mentha longifolia, Lysimachia numularia, Sapponaria officinalis. Also, there are numerous species that belong to the Alno-Ulmion Alliance, such as Alnus incana, Alnus glutinosa, Stellaria nemorum, Impatiens noli-tangere, Aegopodium podagraria.

Vegetation height reaches $2.50 \mathrm{~m}$, with obvious stratification of the biocoenoses. The bush cover layer ranges from 60 to $75 \%$, and the herbacaeous one from 25 to $45 \%$. In the analysed phytocoenoses was observed the predominance of the Myricaria germanica species, which finds in these area favourable ecological conditions (Table 1).

The field research also revealed the excessive development in some phytocoenoses of Calamagrostis pseudophragmites favoured by the human influence. The great dominating abundance of this perennial grass species in some phytocoenoses, indicates an increase of the anthropogenic pressures in certain sectors of the Lotru river. In these sectors the species finds favourable conditions, taking into account that its developed root system allows the collection of water and essential nutrients from a large surface. The dense root system of the shrubs firmly anchors them in the substrate and thus reduces soil erosion (BuseDragomir and Niculescu, 2016).
The anthropic factors that mostly contribute to the degradation of plant communities are in general: uncontrolled tourism, irrational deforestation in the forest stands, intensive grazing especially with cattle that causes strong soil alteration and prevents the restoration of vegetation, cuttings of wood species, and location near active traffic roads.

The anthropogenic disorders in the area of study have created modifications in the floristic physiognomy and compositions of the phytocoenoses, favouring the invasion of opportunistic species such as Ambrosia artemisiifolia, Impatiens glandulifera, Phytolacca amearicana, Amorpha fruticosa, Erigeron annuus which conquer territories more and more extended in the area of study. The pressures that threaten this community plant in the area of study are: intensive mixed animal grazing, forest exploitations, roads, motorways paths, tracks, cycling tracks, continuous urbanisation, invasive non-native species, modification of

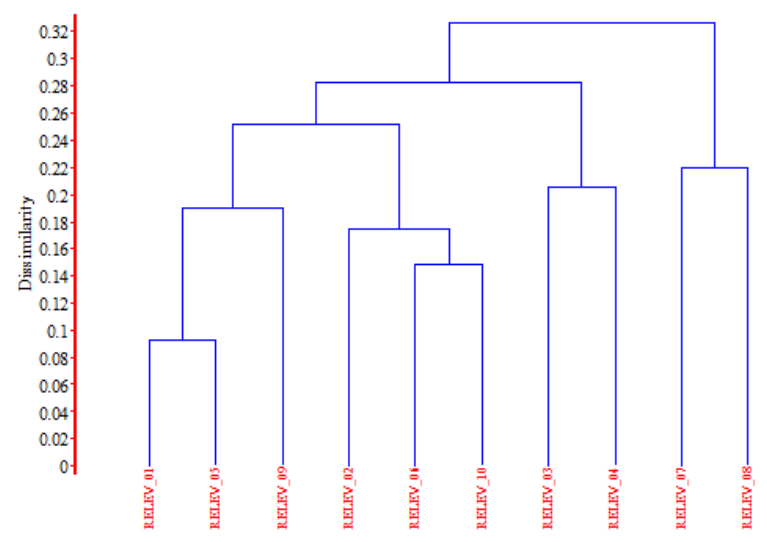

Fig. 3. Clustering of Salici purpurae-Myricarietum germanicae relevés based on UPGMA Bray Curtis index 
626

hydrographic functioning, modification of water flow, anthropogenic reduction of habitat connectivity, accumulation of organic material, species composition change (succession), climate change (flooding and rising precipitations, water flow changes), uncontrolled tourism. However, the most important menace for this plant community in the Lotru Valley are the new skiing complex from Vidra and the camping and caravans of the illegal mushrooms and berries collectors.

A special attention was paid to the calculation of the quantitative index Bray-Curtis and a dendogram was performed, by the Group-Average method (UPGMA) using the program Syn-Tax 2000 (Podani, 2001). The cluster (Fig. 3) is divided into two main groups, one grouping the relevés no. 1, 5, 9, 2, 6, 10 and the other one relevés 3, 4, 7 and 8. As it can be seen in Fig. 2 relevés in the second group are characterized by the absence of Deschampsia caespitosa, present in all the others.

The branches of the dendrogram are well individualised. The quantitative values of the Bray-Curtis index vary between 0.32 and 0.02 , indicating a high floristic heterogeneity. In the first cluster relevé 9 is separated by the presence of the species Salix purpurea, absent in all the others.

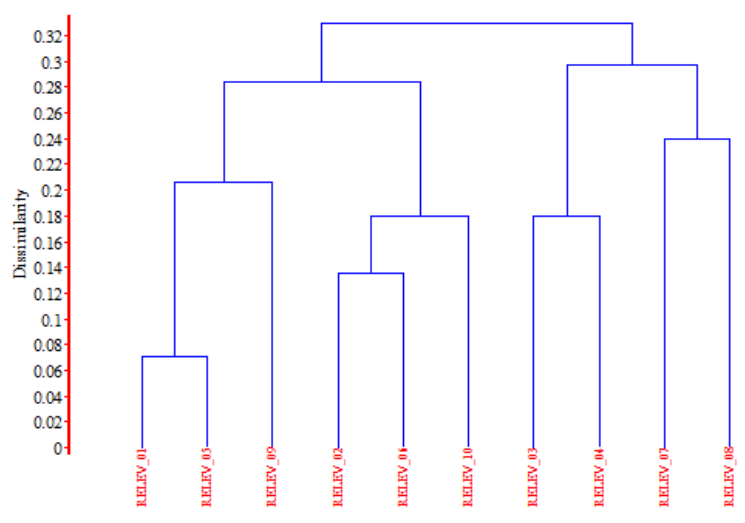

Fig. 4. Clustering of Salici purpurae-Myricarietum germanicae relevés based on UPGMA Sorrensen index

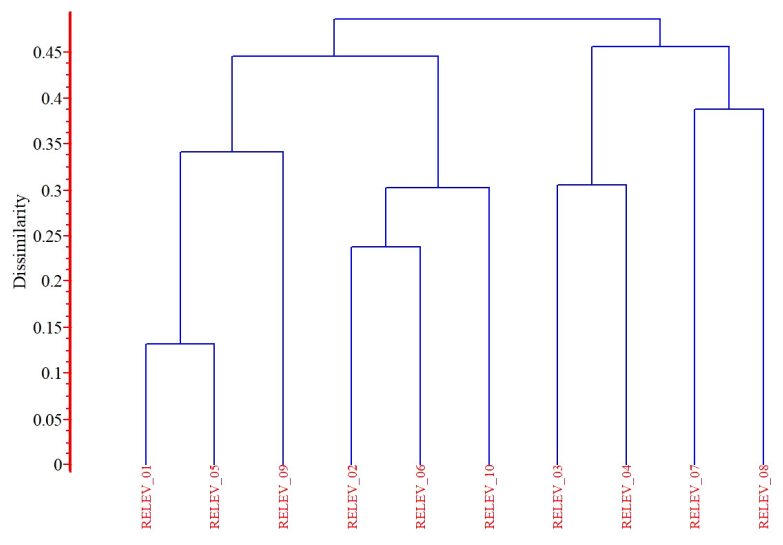

Fig. 5 Clustering of Salici purpurae-Myricarietum germanicae relevés based on UPGMA correlations

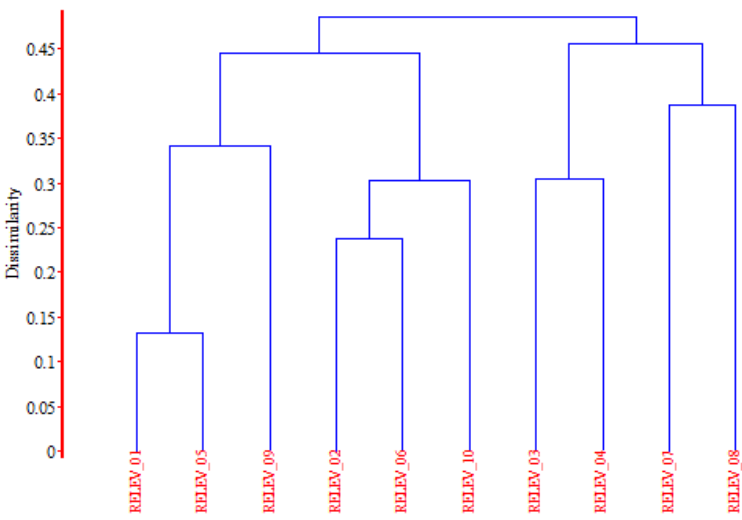

Fig. 6. Clustering of Salici purpurae-Myricarietum germanicae relevés based on UPGMA correlations

In addition, the Sørensen qualitative index, Correlation index using the Group-Average method (UPGMA), and the Jaccard index, using the WPGMA method were calculated. Dendrograms were obtained using the same program - SYN-TAX 2000 (Podani, 2001). Such dendrograms allow measuring the functional diversity of plant communities. The composition of the functional groups of phytocenosis varies under the effect of human activities and according to eco-pedo-climatic conditions of the last years. Another utility of this type of analysis is that it represents a tool for the better understanding of how plant communities function. Variations in the floristic physiognomy and compositions of the phytocoenoses reflect the way plant communities respond to human influence. The dendrogram obtained by the Group-Average method (UPGMA) and the Sørensen qualitative index, highlighted the separation of two distinct clusters, which according to their qualitative index values are very close (Fig. 4).

In this dendrogram can be noticed the separation of the $9^{\text {th }}$ and $10^{\text {th }}$ relevés, from the first cluster, based on individual number of species and on the number of species in common. Also, relevés 9 and 10 stand out by the presence of numerous individuals of Agrostis stolonifera and Phytolacca americana due to the effects of anthropic pressure in these phytocoenoses.

In the dendrogram of the Salici purpureae-Myricarietum plant community obtained by the UPGMA method and Correlation index, also two distinct clusters appear. The first cluster includes relevés no. 9, 4, 2 and 3, especially due to the environmental conditions favouring the species for Aegopodium podagraria and Lysimachia nummularia. In the second cluster relevés 7 and 8 are grouped together due to the abundance-dominance of the species Ambrosia artemisiifolia (Fig. 5).

The dendrogram obtained by the WPGMA method and Jaccard index also indicate two distinct clusters that are separated by the degree of similarity between the analyzed phytocenoses (Fig. 6). The Jaccard index has the value of 0.45 which means that the degree of similarity is $45 \%$ for the analysed phytocenoses. This is explained by an increasing human impact in these phytocoenoses from the area of study. 


\section{Syndinamics}

If the water regime is not disturbed the phytocoenosis constituted by Salix purpurea and Myricaria germanica usually suffers small changes in time. Sometimes, it can evolve towards plant communities dominated by Juncus effusus or to degraded grassland communities from the Agropyro - Rumicion Alliance. The presence of the AlnoUlmion Alliance species indicates that this group can progress from the syndynamic point of view to the phytococenoses of Alnus incana, but anthropogenic factors may disrupt this evolution in some phytocoenoses, especially in the Obirsia Lotrului area.

\section{Ecology}

Considering the mean abundance - dominance of the species, the plant community shaped by Salix purpurea and Myricaria germanica is dominated by mesophilous, followed by mesohigrophilous elements. According to the temperature factor, the micromesotherm species are the most abundant, followed by the eurytherm ones. Taking into account the soil reaction one can notice the predominance of the euri-ionic species, followed by the weak acid neutrophils. In the floristic composition of this plant community are found also numerous hygrophilous species, such as: Scirpus sylvaticus, Agrostis stolonifera, Alnus glutinosa, Alopecurus pratensis, Caltha palustris, Carex sp., Cirsium canum, C. oleraceum, Deschampsia caespitosa, Filipendula ulmaria, Juncus conglomeratus, J. effusus, J. inflexus, Lysimachia nummularia, L. vulgaris, Lythrum salicaria, Mentha aquatica, Myosotis scorpioides.

\section{Conclusions}

The floristic composition and community structure of Salici purpureae-Myricarietum germanicae is mainly determined by geological and pedo-climatic condition, but it is strongly influenced by the human activities, which disturbed the equilibrium of the ecosystem and implicitly affected the entire vegetation layers. The results here obtained reflect the physiognomy, floristic composition, and ecology of this plant community in the area of Lotru River, and reveal that its conservation is affected by the presence of invasive and opportunistic species. The floristic and vegetation study performed indicate that the structure of willow community with false tamarisk was modified under the stress induced by the anthropogenic pressure. However, in some phytocoenoses characteristic species maintained a high constant presence due to their wide ecological amplitude and greater adaptability to the anthropogenic and biotic influences.

\section{Acknowledgements}

This research received no specific grant from any funding agency in the public, commercial, or not-for-profit sectors.

\section{Conflict of interest}

The authors declare that there is no conflict of interest regarding the publication of this article.

\section{References}

Brand RF, Rostal MK, Kemp A, Anyamba A, Zwiegers H, Van Huyssteen CW, Paweska JT (2018). A phytosociological analysis and description of wetland vegetation and ecological factors associated with locations of high mortality for the 2010-11 Rift Valley fever outbreak in South Africa. PloSOne 13(2):e0191585.

Bray JR, Curtis JT (1957). An ordination of upland forest communities of southern Wisconsin. Ecological Monographs 27(4):325-349.

Braun-Blanquet J, Jenny H (1939). Vegetations-Entwicklung und Bodenbildung [Vegetation development and soil formation]. Denkschriften derSchweizerischen Naturforschung,Zürich, pp 63.

Brown LR, Du Preez PJ, Bezuidenhout H, Bredenkamp GJ, Mostert THC, Collins NB (2013). Guidelines for phytosociological classifications and descriptions of vegetation in southern Africa. Koedoe 55(1):a1103.

Buse-Dragomir L, Niculescu M (2016). Physiological particularities of Myricaria germanica species in climatic conditions of Natura 2000 Domogled-Cerna Valley site. Annals of the University of Craiova Agriculture, Montanology, Cadastre Series 46(2):76-83.

Ciocârlan V (2009). Illustrated flora of Romania. Pteridophyta et Spermatophyta (in Romanian). 3rd ed. Ed Ceres, Bucharest, pp 114.

Chytrý M (2013). Salici purpureae-Myricarietum germanicae Moor 1958. In: Chytrý M(Ed). Vegetace České republiky. Lesní a křovinná vegetace [Vegetation of the Czech Republic. Forest and shrub vegetation]. Academia, Praha 4:60-63.

Coldea G (1991). Prodrome des associations végétales des Carpates du SudEst (Carpates Roumaines) [Prodrome of plant associations of South East Carpathians (Romanian Carpathians]. Camerino, Università degi Studi, Nouvelle Série13:319-539.

Coldea G, Indreica A, Oprea A (2015). Les associations vegetales de Roumanie. Les associations forestieres et arbustives [The plant communities in Romania. The forest and shrub plant communities]. Presa Universitara Clujeanaand Accent. Tome 3:81.

Council Directive 92/43/EEC (1992). Council Directive 92/43/EEC of 21 May 1992 on the conservation of natural habitats and of wild fauna and flora. Annex I(Habitats Directive) 15(02):109-152.

Donita N, Popescu A, Pauca-Comanescu M, Mihailescu S, Biris IA (2005). Habitatele din România [Habitats from Romania]. Ed. Tehnica Silvica, Bucuresti.

Gafta D, Mountford O (2008). Manual de interpretare a habitatelor Natura 2000 din România [Romanian Manual for Interpretation of EU Habitats]. Risoprint Press, Cluj-Napoca, pp 101.

IUCN (2018). The IUCN Red List of Threatened Species. Version 2018-1. http://www.iucnredlist.org(Downloaded on 05 July 2018).

Marinov Y, Dimitrov D, Gussev C, Pachedjieva K (2017). Current status, distribution and habitat of the threatened species Myricaria germanica (Tamaricaceae) in Bulgaria. Bulletin of the Natural History Museum Plovdiv 2:21-28. 
628

Moor M (1958). Pflanzengesellschaften schweizerischer Flußauen [Plant communities of Swiss river meadows]. Mitteilungen - Schweizerische Anstalt für das Forstliche Versuchswesen 34(4):221-360.

Mucina L, Bültmann H, Dierßen K, Theurillat JP, Raus T, Čarni A, .. Tichý L (2016). Vegetation of Europe: hierarchical floristic classification system of vascular plant, bryophyte, lichen, and algal communities. Applied Vegetation Science 19(Suppl. 1):3-264.

Müller N, Scharm S (2001). The importance of seed rain and seed bank for the recolonisation of gravel bars in alpine rivers. University of Applied Sciences Erfurt, Dep Landscape Management \& Restoration Ecology. Leipziger Germany,pp 127-140.

Nicolin AL, Niculescu M, Pauca-Comanescu M (2008). Habitat 3230 Alpine rivers and their ligneous vegetation with Myricaria germanica in Natura 2000 in Romania-Habitat fact sheets, pp 62.

Niculescu M (2006). Flora si vegetatia bazinului superior al raului Luncavat [Flora and vegetation in the upper basin of the Luncavat River]. PhD Thesis, Babes-Bolyai University, Cluj-Napoca, pp 357.

Pazmany D (1969). About the Salici-Myricarietum Moor 58 associations from northern Transilvania. Notulae Botanicae Horti Agrobotanici Cluj-Napoca4(2):71-76.
Podani J (2001). SYN-TAX 2000. Computer programs for data analysis in ecology and systematics. User's manual. Scientia, Budapest, HU.

Rodwell JS, Schaminée JHJ, Mucina L, Pignatti S, Dring Moss JD (2002). The diversity of European vegetation. Raport EC-LNV no. 2002/054, pp 168.

Sanda V, Popescu A, Stancu D (2001). Coenotic structure and ecological characterization of the phytocoenosis of Romania. Vergiliu Publishing House, Bucharest, pp 365

Schletterer M, Scheiber T (2008). Wiederansiedlung der Deutschen Tamariske (Myricaria germanica (L.) DESV.) an der Leutascher Ache (Nordtirol, Österreich). [Resettlement of the German tamarisk (Myricaria germanica (L.) DESV.) at the Leutascher Ache (North Tyrol, Austria)]. Berichte des Naturwissenschaftlichen-Medizinischen Verein Innsbruck 95:53-65.

Thiele J, Schirmel J, Buchholz S (2018). Effectiveness of corridors varies among phytosociological plant groups and dispersal syndromes. PLoS One 13(7):e0199980. 